\title{
Postoje univerzitních studentů pedagogicky orientovaných studijních programů k homosexualitě měřené na škále Homosexuality Attitude Scale
}

\author{
Petr Hlad'o \\ Institut celoživotního vzdělávání, Mendelova univerzita v Brně \\ Redakci zasláno 10.1. 2015 / upravená verze obdržena 16. 4. 2015 / \\ k uveřejnění přijato 18. 4. 2015
}

\begin{abstract}
Abstrakt: Cílem studie je zhodnotit postoje studentů pedagogicky orientovaných studijních programů $\mathrm{k}$ homosexualitě a zjistit, čím jsou ovlivněny. V př́spěvku je argumentován význam tématu $\mathrm{v}$ rámci pedagogiky, podán přehled závěrů vybraných českých a zahraničních výzkumů vztahujících se k problematice postojů heterosexuálů $\mathrm{k}$ homosexualitě. Dále jsou prezentovány cíle, metodologie a poznatky z vlastního výzkumného šetření. V závěru jsou prezentována doporučení pro pregraduální vzdělávání budoucích pedagogů a podány návrhy pro další výzkum. Cílem výzkumu bylo zjistit postoje studentů pedagogicky orientovaných studijních programů k homosexualitě. Použitým výzkumným nástrojem byl dotazník Kiteové a Deauxové - Homosexuality Attitude Scale (Cronbachovo alfa $=0,91$ ). Sběr dat proběhl v ř́jnu a listopadu 2014. Výběrový soubor je tvořen 1140 respondenty. Studenti pedagogických studijních programů mají $\mathrm{v}$ průměrném hodnocení $\mathrm{k}$ homosexualitě poměrně pozitivní postoje (průměrné skóre HAS $=88,77$ z teoretického rozmezí $12-105$, nižší hodnota indikuje negativnější postoj k homosexualitě). Signifikantně negativnější postoje $\mathrm{k}$ homosexualitě byly zjištěny u mužů, studentů nižších ročníků studia a př́íslušníků ř́msko-katolické či jiné církve nebo náboženské společnosti. Z poznatků vyplývá potřeba formování postojů budoucích pedagogů k homosexualitě kombinací kognitivně-afektivních intervencí v rámci formálního vzdělávání.
\end{abstract}

Klíčová slova: postoje k homosexualitě, postoje pedagogů, Homosexuality Attitude Scale, homosexualita, sexuální předsudky, sexuální diskriminace 


\section{Význam tématu v rámci pedagogiky a vymezení cíle příspěvku}

Přestože homosexualita ${ }^{1}$ není v České republice více než 20 let klasifikována jako duševní onemocnění, jde stále o téma tabuizované (Kamanová, 2014). Předsudky vůči homosexuálům mají hluboké historické kořeny a v české společnosti přetrvávají (Vaculík \& Červenková, 2007).

Závažnost sexuálních předsudků tkví zejména $v$ tom, že se mohou projevovat $\mathrm{v}$ nepřátelském až agresivním chování $\mathrm{k}$ jedincům $\mathrm{s}$ homosexuální orientací, a to bud' ve formě verbální, nebo fyzické agrese (Vincent, Parrott, \& Peterson, 2011). Rivers a D’Augelli (2001) zdokumentovali, že lesby a gayové jsou kvůli své sexuální orientaci objektem šikany, obtěžování a fyzického napadání či týrání různými skupinami a jedinci - vrstevníky, rodiči, ale také učiteli. Uvedené skutečnosti ve školním prostředí potvrzuje výzkum u žáků ve věku 13-21 let ( $N=7898)$ ve Spojených státech amerických, z nichž se 59 \% identifikovalo jako gayové nebo lesby (Kosciw et al., 2014, s. 16-17). Z výzkumu vyplývá, že se ve škole více než polovina žáků (56\%) necítila kvůli své sexuální orientaci bezpečně, přičemž $\mathrm{v}$ posledním roce bylo $\mathrm{z}$ tohoto důvodu obtěžováno slovně $74 \%$ a fyzicky $36 \%$ žáků. Fyzicky napadeno bylo za stejné období $17 \%$ žáků. Elektronickou formu šikany zažilo $49 \%$ žáků. Alarmující je, že 51 \% žáků slyšelo homofobní poznámky dokonce od svých učitelů a dalších zaměstnanců školy a v případě, že se stali obětí incidentu ze strany heterosexuálních spolužáků, tuto skutečnost v 57 \% případů neohlásili svým učitelům. Nejčastěji z důvodu pochybností, že by učitelé v dané situaci přiměřeně zakročili, nebo proto, že by nahlášení vedlo ke zhoršení jejich osobní situace ve škole. Pechová $(2009$, s. 11) u českých leseb, gayů a bisexuálů $(N=497)$ zjistila, že se v některých př́ípadech pedagogičtí pracovníci

1 Homosexualitu pro účely našeho výzkumu ve shodě s Vaculíkem a Červenkovou (2007, s. 59) definujeme jako „celoživotní a stálou eroticko-sexuální orientaci jedince na osoby stejného pohlaví".

2 Pojem sexuální předsudky se podle Hereka (2000b, s. 19) vztahuje na všechny negativní postoje založené na sexuální orientaci. Sexuální předsudky mají podle uvedeného autora tři rysy: reprezentují postoje, které jsou zaměřeny na sociální skupiny a její členy a jsou negativní, tedy zahrnují nepřátelství nebo odpor.

Pro pojmenování hostility $\mathrm{k}$ homosexuálům budeme používat pojem homofobie. Hudson a Ricketts (1980, s. 357) homofobii definují jako jednodimenziální konstrukt složený z různých emocionálních reakcí (napřs. strach, hněv, znechucení), které jedinci pocitují při interakci s homosexuály. 
sami podílejí na jejich diskriminaci či obtěžování, nebo o tomto jednání ví a mlčky jej přehlížejí.

Negativní vlivy diskriminačních postojů mohou mít dopad na duševní zdraví homosexuálně orientovaných jedinců již během dospívání a ztěžovat nejdůležitější psychologický úkol tohoto vývojového období - nalezení vlastní identity, zrání osobnosti s kladným sebehodnocením a pozitivními životními cíli. Sociální tlaky ve školním prostředí mohou komplikovat proces coming-outu, jenž je zásadní pro psychosociální adaptaci a odpovědnější a bezpečnější sexuální chování (Stehlíková, Procházka, \& Hromada, 1995).

Výzkumy potvrdily vztah mezi šikanováním leseb a gayů ve škole nebo vnímanou diskriminací na základě sexuální orientace a řadou negativních důsledků, mezi něž se řadí vyšší výskyt záškoláctví, nižší vzdělanostní aspirace a školní úspěšnost (Kosciw et al., 2012) a předčasné odchody ze vzdělávání (Mishna et al., 2009). Dále bylo zjištěno, že šikanování a diskriminace homosexuálů ve škole či problémy kvưli homosexuální orientaci v rodině pozitivně korelují s užíváním návykových látek (Almeida et al., 2009), rizikovým sexuálním chováním (Bontempo \& D’Augelli, 2002), útěky z domova a bezdomovectvím (Cochran et al., 2002), prostitucí (Savin-Williams, 1994) a dalšími poruchami chování (Murdock \& Bolch, 2005). U homosexuálů se objevují duševní poruchy, které mohou vyústit v sebevražedné sklony, poněvadž se tito jedinci cítí být odmítnuti sociálním okolím (Haas et al., 2011). Eisenbergová a Resnick (2006, s. 665) u homosexuálních žáků 9. až 12. ročníkủ $^{3}(N=2255)$ v americkém státě Minnesota zjistili, že více než polovina (54 \%) o sebevraždě přemýšlela a více než třetina (36 \%) měla za sebou pokus o sebevraždu. Výzkum jmenovaných autorů přinesl i další významný poznatek. Protektivními faktory sebevražedných myšlenek a pokusů žáků s homosexuální orientací byly rodinná koheze, péče dospělých a pocit bezpečí ve škole.

Kapacitou k sociálně-strukturálním intervencím, jež mohou vést ve školách $\mathrm{k}$ prosazování protektivního přístupu $\mathrm{k}$ žákủm $\mathrm{s}$ homosexuální orientací, ale i $\mathrm{k}$ intervencím na individuální úrovni například v podobě poskytování otevřené podpory homosexuálním žákům, disponují učitelé (Graham, 2012). Ke zvýšení bezpečí a ochrany zdraví žáků s homosexuální orientací

3 Charakteristika výzkumného vzorku prezentovaná ve studii Eisenbergové a Resnicka (2006, s. 663) zahrnuje pouze ročník studia, nikoliv věk respondentů. Ve Spojených státech amerických je typický věk žáků 9. ročníků 14-15 let a žáků 12. ročníků 18-19 let. 
ve školách mohou učitelé přispět rovněž tím, že budou u vychovávaných jedinců rozvíjet respekt vůči sexuální diverzitě (Farr, 2000).

Bylo prokázáno, že plánované i spontánní chování jedince je ovlivňováno zastávanými postoji (Fazio, 1990). Předpokladem rozvoje suportivního školního prostředí pro homosexuální žáky jsou pozitivní postoje pedagogů, které regulují nejen jejich vlastní chování vůči žákům s homosexuální orientací, ale mohou rovněž ovlivnit postoje a chování ostatních žákư (Fontaine, 1998). Naopak, negativní postoje pedagogů se mohou projevit v nedostatku ochoty pomoci této skupině žáků (Tsang, 1994).

Připravit pedagogy na práci s diverzifikovanou populací žáků, do níž patří žáci s odlišnou sexuální orientací, formovat u nich žádoucí postoje je cílem pregraduálního vzdělávání. Zahraniční empirické důkazy na druhou stranu svědčí o tom, že část budoucích pedagogů vykazuje homofobní postoje (srov. Riggs, Rosenthal, \& Smith-Bonahue, 2011). Sears (1992 in Riggs et al., 2011, s. 202) zkoumal postoje studentů učitelství k homosexualitě a homosexuálům žijícím v oblasti jihovýchodních a jižních Spojených států amerických a zjistil, že $52 \%$ by vadilo mít kolegu či kolegyni s homosexuální orientací, $77 \%$ by nepodporovalo ve své tř́dě diskuzi o homosexualitě, $85 \%$ by nebylo ochotno integrovat do kurikula učivo o homosexualitě a pouze $40 \%$ budoucích učitelů by bylo ochotno do své třídy přijmout homosexuálního žáka z důvodu jeho diskriminace homofobním třídním učitelem. K prezentovaným poznatkům je nezbytné dodat, že Sears zjišt'oval postoje u výzkumného souboru v geografické oblasti, kde v kulturní orientaci dominuje konzervativní protestantismus, pro který jsou typické silně negativní postoje vůči homosexualitě (srov. Adamczyk \& Pitt, 2009, s. 339).

S ohledem na empiricky podloženou argumentaci je cílem předkládané studie zhodnotit aktuální postoje studentů pedagogicky orientovaných studijních programů k homosexualitě v českém prostředí a zjistit, čím jsou ovlivněny. Znalost postojů budoucích pedagogů k této sexuální minoritě považujeme ve shodě s Wyattovou et al. (2008) za důležitou zejména pro inovaci př́pravného vzdělávání budoucích pedagogů a návrh změn v edukační realitě, které by směřovaly ke zlepšení školního klimatu pro homosexuální žáky. 


\section{Postoje $\mathbf{k}$ homosexualitě jako téma výzkumů ${ }^{4}$}

$\mathrm{V}$ českém prostředí byly postoje $\mathrm{k}$ homosexualitě zjištovány jak u dospělé populace (Janošová, 2000; Weiss, Procházka, \& Zvěřina, 1998; Weiss \& Zvěřina, 1997; Tuček \& Holub, 1994), tak u žáků základních a středních škol (Emmerová et al., 2010; Network Media Service, 2007). Postoje českého obyvatelstva ve věku od 15 let k lidem s odlišnou sexuální orientací ve svých pravidelných šetřeních na reprezentativním výzkumném vzorku zjišt’uje Sociologický ústav Akademie věd České republiky. Z časového srovnání vyplývá, že se postoje české společnosti k homosexuálům zlepšují (srov. Tuček, 2014; Rezková, 2003). Jak ukázal průzkum Ďurd’oviče (2013, s. 4) na výběrovém vzorku vzniklém kvótním výběrem u obyvatelstva ve věku od 15 let $(N=1062)$, lidé se v České republice nejtolerantněji staví k právům homosexuálů na uzavření registrovaného partnerství (72\%). Nižší podporu veřejného mínění má povolení uzavření sňatku (51 \%). Nejméně jsou lidé nakloněni k možnosti adopce stejnopohlavními páry (34\%).

Tucker a Potocky-Tripodiová (2006, s. 179-183) dospěli v přehledové studii $\mathrm{k}$ závěru, že větší část zahraničních výzkumů zkoumala postoje $\mathrm{k}$ homosexualitě u populace vysokoškolských studentů. Výjimkou však nebyla ani šetření u dospělých a u specifických profesních skupin - vojáků, sociálních pracovníků, poradenských pracovníků, doktorů, zdravotních sester, učitelů aj. (srov. Pérez-Testor et al., 2010, s. 139). Jednou z hlavních výzkumných oblastí bylo testování vlivu korelátů, především demografických a sociálně-psychologických, na postoje k homosexualitě. Jedním z nejkonzistentnějších výzkumných zjištění je, že heterosexuální muži mají homofobnější postoje než heterosexuální ženy (Thatcher \& Chandler, 2013; Woodford et al., 2012; Herek, 1999, aj.). Autoři některých empirických studií dospěli k závěru, že mladší lidé zaujímají $\mathrm{k}$ homosexualitě či homosexuálům pozitivnější postoje (Collier, Bos, \& Sandfort, 2012), kdežto starší lidé vykazují vyšší míru homofobie (Baker \& Fishbein, 1998). Věřící, zejména praktikující, s konzervativním náboženským přesvědčením, jsou oproti běžné populaci více homofobní, resp. zaujímají negativnější postoje $\mathrm{k}$ homosexualitě či jedincům s odlišnou sexuální orientací (Besen \& Zicklin, 2007; Arndt \& de Bruin, 2006). Řada

\footnotetext{
Prezentované výzkumy se liší charakteristikami výběrového souboru. Některé zjištovaly postoje k homosexualitě výhradně u osob, které se identifikovaly jako heterosexuální. Jiné výzkumy však pracovaly s výběrovým souborem, aniž by byla sexuální orientace respondentů zjištována, př́ípadně byly do analýz zahrnuty odpovědi jak osob s heterosexuální, tak homosexuální či bisexuální orientací.
} 
dřivějších i současných empirických nálezů potvrdila, že osobní znalost lesby či gaye přispívá k pozitivnějším postojům k lidem s touto sexuální orientací (Anderseen, 2002). Na druhou stranu jedinci, kteří nikoho s homosexuální orientací neznají nebo mají s osobami s touto sexuální orientací pouze omezený či př́ležitostný kontakt, vyjadřují $\mathrm{k}$ homosexuálům či homosexualitě negativnější postoje (Collier et al., 2012). Předchozími výzkumy bylo dále prokázáno, že postoje $\mathrm{k}$ homosexualitě do jisté míry souvisí s dosaženým vzděláním (Lambert et al., 2006; Kelly, 2001), výší příjmů, velikostí bydliště (Herek, 1991) a přesvědčením, zdali je homosexualita lidem vrozená, nebo se jedná o dobrovolně zvolený životní styl (Woodford et al., 2012). Jiné práce u populace univerzitních studentů dospěly k závěru, že méně homofobní jsou studenti vyšších ročníků nebo stupňů vzdělání (Hewitt \& Moore, 2002) a humanitních studijních oborů (Schellenberg, Hirt, \& Sears, 1999).

\section{Metodologie výzkumného šetření}

V souladu s definovanými cíli chceme v našem šetření nalézt odpovědi na následující výzkumné otázky:

- Jaké postoje mají současní studenti pedagogicky orientovaných studijních programů k homosexualitě?

- Souvisí postoje studentů pedagogicky orientovaných studijních programů k homosexualitě s jejich pohlavím, velikostí bydliště, navštěvovaným ročníkem studia, studijním oborem, náboženským vyznáním a přítomností homosexuálně orientované osoby v blízkém sociálním okolí?

Na základě studia teorií a předchozích výzkumů stanovujeme následující hypotézy:

- H1: Muži vykazují k homosexualitě negativnější postoje než ženy.

- H2: Studenti žijící v sídlech s menším počtem obyvatel vykazují negativnější postoje $\mathrm{k}$ homosexualitě než studenti žijící v sídlech s větším počtem obyvatel.

- H3: Studenti vyšších ročníků studia vykazují pozitivnější postoje k homosexualitě než studenti nižších ročníků studia.

- H4: Mezi studenty jednotlivých pedagogicky orientovaných studijních oborů nejsou rozdíly v postojích k homosexualitě. 
- H5: Studenti, kteří jsou příslušníky církve nebo náboženské společnosti, vykazují negativnější postoje $\mathrm{k}$ homosexualitě než studenti, kteří nejsou příslušníky žádné církve nebo náboženské společnosti či jsou bez vyznání (ateisté).

- H6: Studenti, kteří mají ve svém nejbližším okolí někoho, o němž ví, že je lesba nebo gay, vykazují pozitivnější postoje k homosexualitě než studenti, kteří lesbu nebo gaye neznají.

\subsection{Výzkumný nástroj}

$\mathrm{K}$ měření postojů $\mathrm{k}$ homosexuálně orientovaným osobám a homosexualitě bylo vyvinuto několik výzkumných nástrojů - Heterosexual Attitudes Toward Homosexuality Scale (Larsen, Reed, \& Hoffman, 1980), Index of Attitudes Toward Homosexuals (Hudson \& Ricketts, 1980), Homosexism Scale (Hansen, 1982), Homosexuality Attitude Scale (Kite \& Deaux, 1986), Attitudes Towards Lesbians and Gay Men Scale (Herek, 1994, 1988), Homonegativity Scale (Morrison, Parriag, \& Morrison, 1999), Riddle Homophobia Scale (Wall, 1995), Modern Homophobia Scale (Raja \& Stokes, 1998), Homophobia Scale (Wright, Adams, \& Bernat, 1999), Modern Homonegativity Scale (Morrison, Kenny, \& Harrington, 2005), Multidimensional Scale of Attitudes Toward Lesbians and Gay Men (Gato, Fontaine, \& Carneiro, 2012) a další.

V českém prostředí nebyl dosud pro měření postojů $\mathrm{k}$ homosexuálně orientovaným osobám a homosexualitě navrhnut validní výzkumný nástroj s dostatečnou reliabilitou, ani nebyl pro české prostředí adaptován některý ze zahraničních dotazníků.

Pro účely našeho výzkumu jsme zvolili dotazník Homosexuality Attitude Scale (Kite \& Deaux, 1986), jehož konečná podoba vzešlá z původního návrhu 40 položek byla ověřena u studentů kurzu úvodu do psychologie na Purdue University v americkém státě Indiana $(N=1342)$. Výzkumný nástroj byl vybrán z několika důvodů. Znění položek reflektuje vědecky popsané stereotypy, miskoncepce a obavy heterosexuálů spojených s homosexualitou. Dotazník dále vykazoval u vysokoškolských studentů výbornou korelaci jednotlivých položek k dané doméně (inter-item correlation), vysokou vnitřní konzistenci (Cronbachovo $\alpha=0,93)$ a dobrou test-retest realibilitu $(r=0,71)$. Z faktorové analýzy vyplynulo, že dotazník měří jeden hlavní faktor (vysvětluje $42 \%$ variance) představující příznivé nebo nepříznivé hodnocení homosexuality (srov. Beere, 1990; Kite \& Deaux, 1986), což koresponduje s cíli naší studie. 
Anglická verze dotazníku byla nejprve přeložena do českého jazyka a následně byl proveden zpětný překlad nezávislým překladatelem do anglického jazyka pro ověření korektnosti překladu. K zajištění obsahové validity byly položky české verze výzkumného nástroje konzultovány s odborníky a srovnány s teoriemi a poznatky z předchozích výzkumů. Upravený nástroj byl pilotně ověřen na vzorku 32 studentů studijního programu Specializace v pedagogice na Mendelově univerzitě v Brně. K posouzení konstruktové validity byla provedena exploratorní faktorová analýza (kap. 4.1). Dotazník má vysokou vnitřní konzistenci. V prezentované studii bylo Cronbachovo $\alpha=0,91$.

Dotazník sestává z 21 výroků mapujících postoje k homosexualitě, z nichž 11 má pozitivní a 10 negativní znění (plné znění výroků viz tabulka 3). Respondenti se k výrokům mohli vyjadřovat na pětibodové Likertově škále řazené od 1 = zcela souhlasím po 5 = zcela nesouhlasím (položky s pozitivním zněním mají převrácené skórování). Celkové skóre (HAS) získané součtem bodů ze všech položek dotazníku se mohlo pohybovat v rozmezí od 21 do 105 (nižší hodnota indikuje negativnější postoj k homosexualitě). Pro identifikaci úrovně postojů jsme navrhli následující rozpětí skóre: $21-37$ = extrémně negativní postoje; $38-54$ = vysoce negativní postoje; $55-71$ = středně negativní postoje; $72-88$ = mírně negativní postoje; $89-105$ = zanedbatelně negativní postoje.

\subsection{Administrace dotazníku a výzkumný soubor}

Anonymní dotazník byl administrován elektronicky ve virtuální laboratoři pro sběr dat Umbrela, jež je spravována Mendelovou univerzitou v Brně. Sběr dat byl uskutečněn v ř́jnu a listopadu 2014.

Nejprve byl vytvořen seznam všech pracovišt' veřejných vysokých škol v České republice, která připravují budoucí pedagogy v bakalářských, navazujících magisterských nebo magisterských studijních programech. Následně byli požádáni děkani nebo relevantní vedoucí pracovníci daných institucí o zaslání hromadného e-mailu studentům s žádostí o vyplnění dotazníku. E-mail studentům rozeslalo sedm fakult a vysokoškolských ústavů․ Vyplnění dotazníků bylo anonymní.

5 S ohledem na zachování anonymity nebyla u respondentů zjišt’ována studovaná vzdělávací instituce a vzhledem k citlivosti tématu neuvádíme ani fakulty a vysokoškolské ústavy, u jejichž studentů sběr dat proběhl. 
Základní soubor představovali všichni studenti veřejných vysokých škol studující v pedagogicky orientovaných studijních programech. V akademickém roce 2014/2015 studovalo v prezenčním, kombinovaném a distančním studiu ve skupině studijních programů Pedagogika, učitelství a sociální péče 35127 studentů (MŠMT, 2015). Dotazník vyplnilo celkem 1235 respondentů6. Johnson a Christensen (2012) u velikosti základního souboru do 100 tis. osob jako adekvátní rozsah výběrového souboru považují 1,5 \% základního souboru. Z kvantitativního hlediska lze proto považovat výběrový soubor za reprezentativní. Použitý způsob sběru dat - samovýběr - však není náhodným výběrem. Zjištěné poznatky z tohoto důvodu nelze považovat za reprezentativní a výsledky šetření nelze zobecňovat.

Z uvedeného počtu uvedlo heterosexuální orientaci 1140 (92,3 \%), bisexuální orientaci $52(4,2 \%)$ a homosexuální orientaci $25(2,0 \%)$ respondentů. Transgenderovou orientaci uvedl 1 respondent $(0,1 \%)$ a 17 respondentů (1,4 \%) nechtělo svou sexuální orientaci uvést. Kiteová a Deauxová (1986, s. 140) ve svých šetřeních za využití Homosexuality Attitude Scale nezjištovaly sexuální preference respondentů. Jejich argumentem bylo, že sexuální orientace by neměla mít vliv na přesnost měření. S ohledem na cíle příspěvku (zjistit postoje heterosexuálních studentů k homosexualitě) a skutečnost, že lze u osob s jinou než majoritní sexuální orientací očekávat pozitivnější postoje k homosexualitě (srov. Jellison, McConnell, \& Gabriel, 2004), byly analyzovány pouze odpovědi respondentů s heterosexuální orientací.

Věk heterosexuálních respondentů se pohyboval v rozmezí 18-61 let $(N=1140 ; M=25,40 ; S D=7,39)$. Demografické charakteristiky výběrového souboru jsou uvedeny v tabulce 1 .

Zvolený způsob sběru dat neumožňuje zjistit návratnost dotazníků. Rovněž není možné stanovit přesný poměr výběrového souboru k souboru základnímu, nebot' jsou dostupné statistické údaje pouze o skupině studijních programů, v níž jsou zahrnuti nejen studenti pedagogiky a učitelství, ale i sociální péče (tato skupina není předmětem našeho zkoumání). 
Tabulka 1

Demografické charakteristiky respondentů a průměrné skóre HAS $(N=1140)$

\begin{tabular}{|c|c|c|c|}
\hline Proměnná & $\mathrm{n}$ & $\%$ & $\begin{array}{l}\text { HAS } \\
(M)\end{array}$ \\
\hline \multicolumn{4}{|l|}{ Pohlaví } \\
\hline Muž & 166 & 14,6 & 83,8 \\
\hline Žena & 974 & 85,4 & 89,6 \\
\hline \multicolumn{4}{|l|}{ Velikost bydliště } \\
\hline Do 199 obyvatel & 32 & 2,8 & 90,6 \\
\hline 200-499 obyvatel & 66 & 5,8 & 86,2 \\
\hline 500-999 obyvatel & 117 & 10,3 & 90,0 \\
\hline $1000-1999$ obyvatel & 90 & 7,9 & 88,9 \\
\hline 2 000-4 999 obyvatel & 171 & 15,0 & 89,6 \\
\hline 5 000-9 999 obyvatel & 100 & 8,8 & 88,8 \\
\hline 10 000-19999 obyvatel & 138 & 12,1 & 86,4 \\
\hline 20 000-49999 obyvatel & 147 & 12,9 & 89,0 \\
\hline 50 000-99999 obyvatel & 56 & 4,9 & 88,6 \\
\hline 100000 a více obyvatel & 223 & 19,6 & 89,2 \\
\hline \multicolumn{4}{|l|}{ Ročník studia } \\
\hline 1. ročník tř́letého Bc. nebo pětiletého Mgr. studia & 350 & 30,7 & 86,8 \\
\hline 2. ročník tříletého Bc. nebo pětiletého Mgr. studia & 291 & 25,5 & 88,8 \\
\hline 3. ročník tříletého Bc. nebo pětiletého Mgr. studia & 191 & 16,8 & 89,9 \\
\hline 4. ročník pětiletého Mgr. studia nebo 1. ročník NMgr. studia & 164 & 14,4 & 90,8 \\
\hline 5. ročník pětiletého Mgr. studia nebo 2. ročník NMgr. studia & 144 & 12,6 & 90,4 \\
\hline \multicolumn{4}{|l|}{ Studijní obor } \\
\hline Učitelství pro MŠ & 20 & 1,8 & 87,6 \\
\hline Učitelství pro 1. stupeň ZŠ & 36 & 3,2 & 86,2 \\
\hline Učitelství pro 2. stupeň ZŠ & 305 & 26,8 & 86,3 \\
\hline Učitelství všeobecně-vzdělávacích předmětů pro SŠ & 38 & 3,3 & 90,9 \\
\hline Lektorství cizího jazyka & 71 & 6,2 & 93,8 \\
\hline Učitelství odborných předmětů pro SŠ & 75 & 6,6 & 88,6 \\
\hline Učitelství praktického vyučování a odborného výcviku & 86 & 7,5 & 88,3 \\
\hline Pedagogika & 45 & 3,9 & 91,5 \\
\hline Sociální pedagogika a pedagogika volného času & 143 & 12,5 & 88,5 \\
\hline Speciální pedagogika & 305 & 26,8 & 89,9 \\
\hline Andragogika & 16 & 1,4 & 93,5 \\
\hline \multicolumn{4}{|l|}{ Náboženské vyznání } \\
\hline Příslušník římsko-katolické církve & 177 & 15,5 & 82,3 \\
\hline Příslušník jiné církve než římsko-katolické & 37 & 3,2 & 79,8 \\
\hline $\begin{array}{l}\text { S vyznáním, ale bez příslušnosti k církvi nebo náboženské } \\
\text { společnosti }\end{array}$ & 338 & 29,6 & 90,2 \\
\hline Bez vyznání (ateista) & 588 & 51,6 & 90,4 \\
\hline \multicolumn{4}{|l|}{ Přítomnost gave nebo lesby v blízkém okolí } \\
\hline Ano & 840 & 73,7 & 89,7 \\
\hline $\mathrm{Ne}$ & 300 & 26,3 & 86,3 \\
\hline
\end{tabular}




\subsection{Statistické testy}

Volba statistických testů byla determinována typem dat, splněním předpokladu normality rozložení dat a homoskedasticity. Za využití ShapiroWilkova testu byly zamítnuty hypotézy o normalitě rozložení dat. Poněvadž byla $p$-hodnota u většiny testů normality nižší než $0,0001^{7}$, neuplatňujeme teorii o centrální limitní větě (Rasch, Teuscher, \& Guiard, 2007). Pro testování homogenity rozptylů byl použit Brown-Forsytheův test, na jehož základě jsme hypotézy o homogenitě rozptylů zamítli. Z uvedených důvodů byl pro testování hypotéz zvolen neparametrický dvouvýběrový Kolmogorovův-Smirnovův test a Kruskal-Wallisova ANOVA. Testy byly provedeny v programu STATISTICA Cz 12 a IBM SPSS Statistics 22.

\section{$4 \quad$ Výsledky a jejich diskuze}

\subsection{Exploratorní faktorová analýza}

Ve snaze o redukci vícedimenzionality byla provedena explorativní faktorová analýza (EFA). Cílem faktorové analýzy bylo vysvětlit variabilitu v proměnných pomocí menšího počtu latentních faktorů. Před použitím faktorové analýzy byly provedeny testy, které legitimizovaly její použití - Kaiser-Mayer-Olkinův test (KMO) a Bartlettův test sféricity. Pro extrakci byla použita metoda hlavních komponent a pro rotaci metoda Biquartimax normalizovaný. Pomocí sutinového grafu bylo zjištěno, že dotazník měří dva faktory, které vysvětlují 48,2 \% celkového rozptylu (tabulka 2). První faktor vysvětluje $42,0 \%$ variance a vystihuje ochotu interakce $s$ homosexuály. Druhý faktor vysvětluje $6,2 \%$ variance a vystihuje viditelnost homosexuality a ohrožení tradičního ř́ádu.

\footnotetext{
7 K zesymetričtění rozdělení výběru nedošlo ani při Boxově-Coxově transformaci dat.
} 
Tabulka 2

Exploratorní faktorová analýza

\begin{tabular}{lll}
\hline Výrok & Faktor 1 & Faktor 2 \\
\hline $\begin{array}{l}\text { 1. Nevadilo by mi mít homosexuálního kamaráda/kamarádku } \\
\text { 3. Pokud to mohu ovlivnit, nestýkám se s homosexuály }\end{array}$ & 0,753 & 0,193 \\
$\begin{array}{l}\text { 4. Kdybych se dozvěděl/a, že je můj/moje spolubydlící } \\
\text { homosexuální orientace, hledal/a bych si jiné bydlení }\end{array}$ & 0,689 & 0,368 \\
$\begin{array}{l}\text { 10. Homosexuálové by měli být odděleni od zbytku společnosti } \\
\text { (např. samostatné bydlení, pracovní omezení) }\end{array}$ & 0,685 & 0,336 \\
$\begin{array}{l}\text { 15. Nevadilo by mi, kdyby mě zaměstnával člověk homosexuální } \\
\text { orientace }\end{array}$ & 0,677 & 0,159 \\
$\begin{array}{l}\text { 18. Neodmítl/a bych členství v organizaci jen proto, že někteří } \\
\text { členové jsou homosexuální orientace }\end{array}$ & 0,615 & 0,289 \\
$\begin{array}{l}\text { 20. I kdybych o někom věděl/a, že je homosexuální orientace, pořád } \\
\text { bych s tímto člověkem navázal/a a udržoval/a přátelství }\end{array}$ & 0,753 & 0,125 \\
$\begin{array}{l}\text { 11. Když se dva př́slušníci stejného pohlaví drží za ruce nebo si } \\
\text { projevují náklonnosti na veřejnosti, je to nechutné }\end{array}$ & 0,420 & 0,650 \\
$\begin{array}{l}\text { 13. Homosexuální hnutí vnímám jako pozitivní věc } \\
\text { 14. Pokud jde o můj názor, homosexualita není hřích }\end{array}$ & 0,256 & 0,711 \\
$\begin{array}{l}\text { 17. Rostoucí míra přijatelnosti homosexuality v naší společnosti } \\
\text { přispívá k úpadku morálky }\end{array}$ & 0,373 & 0,620 \\
\hline $\begin{array}{l}\text { Cronbachovo } \alpha \\
\text { Procento vysvětlené variance }\end{array}$ & 0,476 & 0,662 \\
\hline
\end{tabular}

\subsection{Deskriptivní statistiky}

Skóre HAS se u respondentů pohybovalo v rozmezí 25-105, přičemž studenti pedagogicky orientovaných studijních programů měli v průměrném hodnocení k homosexualitě poměrně pozitivní postoje $(N=1140 ; M=88,77$; $S D=12,41)$. Respondenti ve všech sledovaných demografických kategoriích vykazovali bud' zanedbatelně, nebo mírně negativní postoje (tabulka 1). Extrémně nebo vysoce negativní postoje k homosexualitě (HAS $\leq 54)$ zastávalo z celého výběrového souboru pouze $26(2,28 \%)$ respondentů. Středně negativní postoje byly identifikovány již u $92(8,07 \%)$ respondentů. Podrobné informace o hodnocení jednotlivých výroků jsou uvedeny v tabulce 3. 


\section{Tabulka 3}

\section{Deskriptivní statistiky pro výroky v dotazníku}

\begin{tabular}{|c|c|c|c|c|c|}
\hline Výrok & $M$ & $S D$ & $\begin{array}{c}95 \% \text { interval } \\
\text { spolehlivosti (pro } M \text { ) }\end{array}$ & Mod & Med \\
\hline $\begin{array}{l}\text { 1. Nevadilo by mi mít homosexuálního } \\
\text { kamaráda/kamarádku* }\end{array}$ & 4,69 & 0,73 & $(4,64 ; 4,73)$ & 5 & 5 \\
\hline $\begin{array}{l}\text { 2. Zjištění, že je umělec homosexuál, } \\
\text { by nemělo vliv na to, jak jeho tvorbu } \\
\text { oceňuji }^{*}\end{array}$ & 4,61 & 0,92 & $(4,56 ; 4,66)$ & 5 & 5 \\
\hline $\begin{array}{l}\text { 3. Pokud to mohu ovlivnit, nestýkám se } \\
\text { s homosexuály }\end{array}$ & 4,47 & 0,94 & $(4,42 ; 4,53)$ & 5 & 5 \\
\hline $\begin{array}{l}\text { 4. Kdybych se dozvěděl/a, že je můj/moje } \\
\text { spolubydlící homosexuální orientace, } \\
\text { hledal/a bych si jiné bydlení }\end{array}$ & 4,46 & 0,91 & $(4,41 ; 4,51)$ & 5 & 5 \\
\hline 5. Homosexualita je duševní choroba & 4,47 & 1,00 & $(4,42 ; 4,53)$ & 5 & 5 \\
\hline $\begin{array}{l}\text { 6. Nebál/a bych se, kdyby moje dítě mělo } \\
\text { homosexuálního učitele/učitelku* }\end{array}$ & 4,06 & 1,28 & $(3,98 ; 4,13)$ & 5 & 5 \\
\hline $\begin{array}{l}\text { 7. Lidé homosexuální orientace nemají rádi } \\
\text { př́slušníky opačného pohlaví }\end{array}$ & 4,43 & 0,84 & $(4,38 ; 4,47)$ & 5 & 5 \\
\hline $\begin{array}{l}\text { 8. Představa homosexuálních aktů mi } \\
\text { nepřipadá tak nechutná* }\end{array}$ & 2,92 & 1,22 & $(2,85 ; 2,99)$ & 3 & 3 \\
\hline $\begin{array}{l}\text { 9. U homosexuálů je vyšší } \\
\text { pravděpodobnost deviantních } \\
\text { sexuálních činů, jako je zneužívání } \\
\text { dětí, znásilnění a voyeurismus, než } \\
\text { u heterosexuálů }\end{array}$ & 4,28 & 0,94 & $(4,22 ; 4,33)$ & 5 & 5 \\
\hline $\begin{array}{l}\text { 10. Homosexuálové by měli být odděleni } \\
\text { od zbytku společnosti (např. } \\
\text { samostatné bydlení, pracovní omezení) }\end{array}$ & 4,79 & 0,65 & $(4,75 ; 4,83)$ & 5 & 5 \\
\hline $\begin{array}{l}\text { 11. Když se dva příslušníci stejného } \\
\text { pohlaví drží za ruce nebo si projevují } \\
\text { náklonnosti na veřejnosti, je to } \\
\text { nechutné }\end{array}$ & 3,93 & 1,19 & $(3,86 ; 4,00)$ & 5 & 4 \\
\hline $\begin{array}{l}\text { 12. Láska mezi dvěma muži nebo dvěma } \\
\text { ženami se podstatně liší od lásky mezi } \\
\text { dvěma osobami opačného pohlaví }\end{array}$ & 4,02 & 1,15 & $(3,96 ; 4,09)$ & 5 & 4 \\
\hline $\begin{array}{l}\text { 13. Homosexuální hnutí vnímám jako } \\
\text { pozitivní věc }{ }^{*}\end{array}$ & 3,32 & 1,12 & $(3,26 ; 3,39)$ & 3 & 3 \\
\hline $\begin{array}{l}\text { 14. Pokud jde o můj názor, homosexualita } \\
\text { není hřích* }\end{array}$ & 4,30 & 1,17 & $(4,23 ; 4,37)$ & 5 & 5 \\
\hline $\begin{array}{l}\text { 15. Nevadilo by mi, kdyby mě zaměstnával } \\
\text { člověk homosexuální orientace* }\end{array}$ & 4,56 & 0,86 & $(4,51 ; 4,61)$ & 5 & 5 \\
\hline
\end{tabular}


Tabulka 3

(pokračování)

\begin{tabular}{|c|c|c|c|c|c|}
\hline Výrok & $M$ & $S D$ & $\begin{array}{c}95 \% \text { interval } \\
\text { spolehlivosti (pro } M \text { ) }\end{array}$ & Mod & Med \\
\hline $\begin{array}{l}\text { 16. Homosexuálové by měli být donuceni } \\
\text { k psychologické léčbě }\end{array}$ & 4,70 & 0,72 & $(4,65 ; 4,74)$ & 5 & 5 \\
\hline $\begin{array}{l}\text { 17. Rostoucí míra přijatelnosti } \\
\text { homosexuality v naší společnosti } \\
\text { přispívá k úpadku morálky }\end{array}$ & 4,19 & 1,12 & $(4,12 ; 4,25)$ & 5 & 5 \\
\hline $\begin{array}{l}\text { 18. Neodmítl/a bych členství v organizaci } \\
\text { jen proto, že někteří členové jsou } \\
\text { homosexuální orientace }^{*}\end{array}$ & 4,42 & 1,09 & $(4,35 ; 4,48)$ & 5 & 5 \\
\hline $\begin{array}{l}\text { 19. Ve volbách do veřejné funkce bych } \\
\text { volil/a homosexuála }\end{array}$ & 3,55 & 1,07 & $(3,49 ; 3,61)$ & 3 & 3 \\
\hline $\begin{array}{l}\text { 20. I kdybych o někom věděl/a, že je } \\
\text { homosexuální orientace, pořád } \\
\text { bych s tímto člověkem navázal/a } \\
\text { a udržoval/a přátelství* }\end{array}$ & 4,66 & 0,73 & $(4,61 ; 4,70)$ & 5 & 5 \\
\hline $\begin{array}{l}\text { 21. Kdybych byl/a rodičem, dokázal/a } \\
\text { bych přijmout, že můj syn/dcera je } \\
\text { homosexuál/ka }\end{array}$ & 3,97 & 1,02 & $(3,91 ; 4,03)$ & 5 & 4 \\
\hline
\end{tabular}

Pozn. $M$ může u jednotlivých výroků nabýt hodnoty $1-5$ (1 = zcela souhlasím; 2 = spíše souhlasím; 3 = ani souhlasím, ani nesouhlasím; 4 = spíše nesouhlasím; 5 = zcela nesouhlasím). Čím je hodnota $M$ nižší, tím je průměrný názor respondentů na daný výrok negativnější.

* Položka má převrácené skórování.

Negativní postoj respondenti vyjádřili nejvíce u výroku: „Představa homosexuálních aktů mi nepřipadá tak nechutná" $(M=2,92 ; S D=1,22)$. Vysvětlení lze nalézt v kvalitativní studii Vaculíka a Červenkové (2007, s. 64), kteří se pokusili identifikovat vlivy formující postoje k homosexualitě. Silným vlivem formování negativního postoje se zdá být sexuální aspekt homosexuality, tj. pocity, které vyvolává představa intimního homosexuálního chování. Respondenti s negativními postoji vůči homosexualitě se shodovali v tom, že si zpravidla představují intimní chování homosexuálních mužů, nikoliv žen. Tento poznatek podle autorů studie odpovídá výsledkům dřivějších výzkumů o vnímání homosexuality jako záležitosti především mužů.

Dále se ukázalo, že budoucí pedagogové nejsou nakloněni homosexuálním hnutím $(M=3,32 ; S D=1,12)$ a jako zástupci ve veřejných funkcích by nechtěli osobu s homosexuální orientací $(M=3,55 ; S D=1,07)$. Odpovědi respondentů 
na dané výroky svědčí o tom, že jsou ochotni tolerovat homosexualitu, pokud se homosexuálové „drží v ústraní“ a nesnaží se aktivně zasahovat do společenského řádu. Røthingová a Svendsenová (2010, s. 149-150) na příkladu norského školství ilustrují, že pojetí výuky k toleranci vede k zdůrazňování rozdílů mezi homosexualitou a heterosexualitou. Homosexuálové jsou v jejím důsledku vnímáni jako osoby odlišné, k nimž by měli ostatní přistupovat s tolerancí, respektem či dokonce soucitem, což může vést $\mathrm{k}$ vymezení se heterosexuálů vůči této skupině a jejím zájmům. Skutečnost, že respondenti vnímají homosexuální hnutí spíše negativně, může být zapříčiněna rovněž jejich negativním mediálním obrazem. Masmédia jsou totiž podstatným činitelem formování postojů heterosexuálů $\mathrm{k}$ homosexualitě a způsob prezentace v masmédiích pomáhá utvářet názor majoritní společnosti na homosexualitu (Calzo \& Ward, 2009). Důvodem, který by bylo třeba empiricky ověřit, je, že se respondenti názorem vyjádřeným k oběma výrokủm nepř́mo distancují od prosazování společensky kontroverzních práv homosexuály, především homoparentality a legalizace adopce dětí stejnopohlavními páry.

U ostatních výroků respondenti vykazovali vysokou míru tolerance. Pozitivní je, že budoucí pedagogové nemají ve srovnání se zjištěními předchozích českých výzkumů na homosexualitu medicinizující pohledy, resp. nechápou homosexualitu jako nemoc či projev sexuální patologie (srov. Weiss et al., 1998; Gato et al., 2012). Tento závěr lze odvodit z nesouhlasného stanoviska $\mathrm{s}$ výrokem, že homosexuálové by měli být donuceni $\mathrm{k}$ psychologické léčbě $(M=4,70 ; S D=0,72)$.

Pozitivní postoje respondenti vyjadřovali také u položek, které jsou zaměřeny na kontakt s homosexuály: homosexuálové by měli být odděleni od zbytku společnosti $(M=4,79 ; S D=0,65)$; nevadilo by mi mít homosexuálního kamaráda či kamarádku $(M=4,69 ; S D=0,73)$; zjištění, že je umělec homosexuál, by nemělo vliv na to, jak jeho tvorbu oceňuji $(M=4,61 ; S D=0,92)$; i kdybych o někom věděl/a, že je homosexuální orientace, pořád bych $\mathrm{s}$ tímto člověkem navázal/a a udržoval/a přátelství $(M=4,66 ; S D=0,73)$; nevadilo by $\mathrm{mi}$, kdyby mě zaměstnával člověk homosexuální orientace $(M=4,56 ; S D=0,86)$. Pozitivní názory budoucích pedagogů v těchto oblastech jsou předpokladem pro naplnění jedné $\mathrm{z}$ významných zásad vzdělávání, aby interakce všech účastníků vzdělávání byly založeny na vzájemné úctě, respektu, solidaritě a důstojnosti bez ohledu na sexuální orientaci, která je deklarována ve školském zákoně. 
Poněvadž je ochota interakce s homosexuály hlavním faktorem, který dotazník v prezentovaném výzkumu měřil, pozitivní postoje vyjadřované respondenty ke skupině položek zaměřených na kontakt s homosexuály kladně ovlivnily průměrné skóre HAS. Provedené analýzy dat vedou k doporučení, aby byl dotazník rozšířen o položky zaměřené na práva homosexuálů, k nimž se česká populace staví stále negativně (Čadová, 2014; Durd'ovič, 2013).

\subsection{Vliv demografických proměnných na postoje $k$ homosexualitě}

Dvouvýběrovým Kolmogorovovým-Smirnovovým testem byly prokázány statisticky významné rozdíly v postojích $\mathrm{k}$ homosexualitě mezi muži a ženami $(p<0,001)$. Průměrné skóre HAS ukazuje, že muži $(M=83,83 ; S D=14,42)$ vykazují vyšší stupeň předsudků k homosexualitě než ženy $(M=89,62$; $S D=11,84)$. Přijímáme hypotézu 1. Negativnější postoje mužů k homosexualitě jsme s ohledem na zjištění českých i mezinárodních studií očekávali. V kontextu genderových teorií souhlasíme s názorem Smetáčkové (2010), že školy by neměly přehlížet existenci genderových stereotypů - kognitivních schémat, která jsou zobecněním o typických charakteristikách mužů a žen, poněvadž mohou zapříčinit negativní postoje mužů k homosexualitě. Silnější genderová socializace mužů zaměřená na budování heterosexuální mužské identity se totiž projevuje v imperativu odmítání mužské homosexuality, nebot' je spojována s feminitou (srov. Herek, 2000a; Kerns \& Fine, 1994).

Pro zjištění rozdílů v postojích studentů $\mathrm{k}$ homosexualitě na základě velikosti sídla, v němž bydlí, byl použit Kruskal-Wallisův test. Rozdíly v názorech nebyly signifikantní, $H(9, \mathrm{~N}=1140)=11,916 ; p=0,218$. Zamítáme hypotézu 2, že studenti žijící v sídlech s menším počtem obyvatel vykazují negativnější postoje $\mathrm{k}$ homosexualitě než studenti žijící $\mathrm{v}$ sídlech $\mathrm{s}$ větším počtem obyvatel. Statisticky nevýznamné rozdíly v postojích studentů pedagogicky orientovaných studijních programů k homosexualitě podle velikosti bydliště pravděpodobně odráží dnešní menší sociální rozdíly obyvatel měst a venkova (srov. Weiss et al., 1998), ale i skutečnost, že respondenti studují ve velkých městech, která nabízejí větší vizibilitu a př́ležitosti k poznání mediálně nezkreslených atributů homosexuální subkultury.

Studií zaměřených na zhodnocení významu ročníku studia a studijního programu ve vztahu $\mathrm{k}$ postojům studentů $\mathrm{k}$ homosexualitě byl $\mathrm{v}$ zahraničí uskutečněn pouze malý počet (srov. Lambert et al., 2006; Hewitt \& Moore, 2002). Naše výzkumné poznatky tak rozšiřují znalostní bázi o nové informace. Statisticky významné rozdíly byly nalezeny v názorech 
studentů na homosexualitu podle toho, který ročník studia navštěvují, $H(4, \mathrm{~N}=1140)=19,396 ; p=0,001$. Průměrné pořadí bylo 511 u studentů 1. ročníku tř́letého Bc. nebo pětiletého Mgr. studia; 579 u studentů 2. ročníku tř́letého Bc. nebo pětiletého Mgr. studia; 581 u studentů 3. ročníku tříletého Bc. nebo pětiletého Mgr. studia; 621 u studentů 4. ročníku pětiletého Mgr. studia nebo 1. ročníku NMgr. studia; 624 u studentů 5. ročníku pětiletého Mgr. studia nebo 2. ročníku NMgr. studia. Z uvedených hodnot vyplývá, že studenti vyšších ročníků mají k homosexualitě pozitivnější postoje než studenti ročníků nižších. Z vícenásobného porovnání můžeme konstatovat, že studenti 4. ročníku pětiletého Mgr. studia nebo 1. ročníku NMgr. studia $(z=3,523$; $p=0,004)$ a 5. ročníku pětiletého Mgr. studia nebo 2. ročníku NMgr. studia $(z=3,459 ; p=0,005)$ mají $\mathrm{k}$ homosexualitě signifikantně pozitivnější postoj než studenti 1. ročníku tř́letého Bc. nebo pětiletého Mgr. studia. Postoje studentů k homosexualitě se mezi ostatními ročníky neliší $(p>0,05)$. Přijímáme hypotézu 3, že studenti vyšších ročníků studia vykazují pozitivnější postoje k homosexualitě než studenti nižších ročníků studia. Pozitivnější postoje studentů vyšších ročníků studia poukazují na fakt, že univerzitní vzdělávání u budoucích pedagogů nerozvíjí pouze požadované profesní kompetence, ale i respekt $\mathrm{k}$ jinakosti a toleranci vưči sexuálním minoritám. Tento poznatek je dalším argumentem proti objevujícím se snahám o degradaci vzdělání učitelů a zpochybňování nezbytnosti řádného vysokoškolského studia (srov. Janík, Spilková, \& Píšová, 2014).

Dále jsme testovali hypotézu, že mezi studenty jednotlivých pedagogicky orientovaných studijních oborů nejsou rozdíly v postojích $\mathrm{k}$ homosexualitě, $H(10, \mathrm{~N}=1140)=40,818 ; p<0,001$. Hypotézu 4 zamítáme. Postoje studentů $\mathrm{k}$ homosexualitě měly následovné průměrné pořadí (řazeno vzestupně): Učitelství pro 1. stupeň ZŠ (478); Učitelství pro MŠ (496); Učitelství pro 2. stupeň ZŠ (509); Učitelství odborných předmětů pro SŠ (539); Učitelství praktického vyučování a odborného výcviku (551); Sociální pedagogika a pedagogika volného času (566); Speciální pedagogika (599); Učitelství všeobecně-vzdělávacích předmětů pro SŠ (642); Pedagogika (653); Andragogika (696); Lektorství cizího jazyka (727). Post-hoc testem bylo zjištěno, že studenti Lektorství cizího jazyka mají $\mathrm{k}$ homosexualitě pozitivnější postoje než studenti Učitelství pro 1 . stupeň ZŠ $(z=3,686 ; p=0,013)$, Učitelství pro 2. stupeň ŽS $(z=5,019 ; p=0,001)$, Učitelství odborných předmětů pro SŠ $(z=3,444 ; p=0,032)$, Učitelství praktického vyučování a odborného výcviku $(z=3,332 ; p=0,047)$ a Sociální pedagogiky a pedagogiky volného času $(z=3,264 ; p=0,042)$. Dále $\mathrm{k}$ homosexualitě pozitivnější postoje 
vykazují studenti Speciální pedagogiky než studenti Učitelství pro 2. stupeň $Z S ̌ S ~(z=3,381 ; p=0,039)$. S ohledem na poměrně nízký počet respondentů $\mathrm{v}$ některých kategoriích nelze zjištěné poznatky považovat za reprezentativní. Generalizace by byla možná pouze v př́ípadě výzkumu zkoumajícího danou problematiku za využití kvótního výběru u vyššího počtu respondentů. Absence teoretických a empirických studií, o něž by bylo možné se opřít, znemožňuje dále adekvátní interpretaci zjištěného stavu.

Rovněž jsme testovali, zdali se liší postoje studentů k homosexualitě podle náboženského vyznání. Průměrné pořadí bylo 399 u př́íslušníků římsko-katolické církve; 398 u příslušníků jiné církve než římsko-katolické; $595 \mathrm{u}$ respondentů s vyznáním, ale bez př́slušnosti k církvi nebo náboženské společnosti; a 619 u respondentů bez vyznání (ateistů). Prokázalo se, že se postoje studentů $\mathrm{k}$ homosexualitě podle náboženského vyznání liší, $H(3, \mathrm{~N}=1140)=72,677 ; p<0,001$. Z vícenásobného porovnání vyplývá, že se signifikantně odlišují postoje $\mathrm{k}$ homosexualitě mezi příslušníky římsko-katolické církve a věřícími, kteří však nejsou příslušníky žádné církve nebo náboženské společnosti $(z=6,403 ; p<0,001)$, a ateisty $(z=7,780$; $p<0,001)$. Statisticky významné rozdíly byly zaznamenány rovněž mezi př́islušníky jiné církve než římsko-katolické a věřícími, kteří nejsou příslušníky žádné církve nebo náboženské společnosti $(z=3,450 ; p=0,003)$, a ateisty $(z=3,955 ; p<0,001)$. Přijímáme hypotézu 5 . Ve shodě s dřívějšími výzkumy jsme potvrdili, že postoje k homosexualitě významně souvisejí s religiozitou. Studenti, kteří jsou příslušníky církve nebo náboženské společnosti mají k homosexualitě negativnější postoje než studenti bez vyznání nebo studenti věřící, ale bez příslušnosti k církvi nebo náboženské společnosti. Postoje respondentů, kteří jsou příslušníky některé z církví nebo náboženských společností, jsou pravděpodobně ovlivněny prrístupem těchto institucí k homosexualitě. Většina církví chápe homosexualitu jako chování nepřirozené, bezbožné a nečisté (Yip, 2005). Přestože je v § 2358 Katechismu katolické církve (Karmelitánské nakladatelství, 2002) uvedeno, že homosexuálové mají být přijímáni s úctou, soucitem a jemnocitem a že je třeba se vůči nim vyhnout jakémukoliv náznaku nespravedlivé diskriminace, jiná oficiální stanoviska římsko-katolické církve (např. encyklika Lumen fidei) předsudky vůči homosexuálům u věřících podporují. Za důležité považujeme upozornit na empiricky podložený fakt, že se jednotlivé církve a náboženské společnosti výrazně liší v míře odsuzování homosexuality, a tím i postoje jejich členů k této sexuální minoritě (srov. Adamczyk \& Pitt, 2009). 
Poslední testovanou hypotézou bylo, že studenti, kteří mají ve svém nejbližším okolí někoho, o němž ví, že je lesba nebo gay, vykazují pozitivnější postoje $\mathrm{k}$ homosexualitě než studenti, kteří lesbu nebo gaye neznají. Hypotézu 6 prijímáme. Dvouvýběrovým Kolmogorovovým-Smirnovovým testem se mezi oběma skupinami studentů prokázaly statisticky významné rozdíly $(p<0,05)$. Průměrné skóre HAS ukazuje, že jedinci, kteří ve svém okolí neznají nikoho s homosexuální orientací $(M=86,32 ; S D=13,98)$, vykazují vyšší stupeň předsudků $\mathrm{k}$ homosexualitě než studenti, kteří ve svém nejbližším okolí znají někoho, o němž ví, že je lesba nebo gay $(M=89,65 ; S D=11,69)$. Tento poznatek je konzistentní se sociálně-psychologickou hypotézou kontaktu Allporta (1954), podle níž bezprostřední interpersonální kontakt členů různých skupin může redukovat meziskupinové předsudky a nepřátelství (Zelová, 2008, s. 365). Osobní známost s homosexuálními osobami se ukazuje jako jeden z nejvýznamnějších možných vlivů formování pozitivního postoje k homosexualitě (srov. Vaculík \& Červenková, 2007). Výsledky výzkumu Heinzeho a Hornové (2009) však potvrzují, že ke zlepšení postoje či předsudků vůči homosexuálům je třeba, aby byl tento vztah dostatečně těsný.

Předložená studie přináší důležitý poznatek, že u studentů pedagogicky orientovaných studijních programů jsou prediktory negativních postojů k homosexualitě (až na proměnnou velikost bydliště) totožné jako u celé populace.

\section{Doporučení pro pregraduální vzdělávání budoucích pedagogů}

Naším cílem bylo prozkoumat, jaké mají studenti pedagogicky orientovaných studijních programů postoje $\mathrm{k}$ homosexualitě. Přestože jsou zjištěné postoje studentů $\mathrm{k}$ homosexualitě převážně liberální, $\mathrm{v}$ individuálních případech respondenti vyjadřovali středně negativní, vysoce negativní či dokonce extrémně negativní postoje (tento př́klon bylo možné sledovat u více než $10 \%$ respondentů). Vzhledem $\mathrm{k}$ závažným dopadům, jež by mohlo mít jejich otevřené prezentování při výchovně-vzdělávací práci s žáky, je zjištěný stav u budoucích pedagogů nežádoucí. Důležitým krokem pro zlepšení pedagogické praxe považujeme nalezení odpovědi na otázku, jakým zpưsobem mohou být $\mathrm{v}$ rámci univerzitního vzdělávání formovány postoje studentů pedagogických oborů k homosexualitě, resp. jak mohou vysoké školy studenty vzdělávat, kultivovat, učit je respektu a otevřenosti k diverzitě, aby byli schopni kvalifikovaně pracovat s homosexuálně orientovanými žáky, poskytovat jim adekvátní pomoc, účinně předcházet a řešit homofobní diskriminaci a aktivně přispívat ke změně školního klimatu. 
Dlouhodobého pozitivního dopadu na formování žádoucích postojů k homosexualitě je možné dosáhnout kombinací kognitivně-afektivních intervencí (Butler, 1995). Povzbudivý je dřívější empirický poznatek, že výchovněvzdělávací působení vede $\mathrm{k}$ signifikantní změně postojů $\mathrm{k}$ homosexualitě především u studentů s negativními postoji (Serdahely \& Ziemba, 1984). $\mathrm{S}$ ohledem na zjištěné rozdílné postoje $\mathrm{k}$ homosexualitě podle pohlaví a náboženského vyznání zvýšenou edukační pozornost vyžadují zejména studenti mužského pohlaví a studenti, kteří jsou příslušníky některé z církví. Revize obsahu pregraduální přípravy by měla být zvážena kompetentními osobami rovněž ve studijních oborech Učitelství pro mateřské školy, Učitelství pro 1. stupeň ZŠ a Učitelství pro 2. stupeň ZŠ, poněvadž jejich studenti zastávali k homosexualitě mírně negativní postoje.

Jedním z přístupů, který lze doporučit, je seznámení studentů s psychologickou podstatou stereotypů, škodlivostí předsudků a zařazení specifických tematických okruhů zaměřených na lidskou sexualitu do formálního kurikula všech pedagogicky orientovaných studijních programů, v nichž budou prezentovány vědecky podložené poznatky o homosexualitě. Vhodnými jsou studijní předměty společného základu orientované na sociální psychologii a multikulturní výchovu. Analýzou studijních programů akreditovaných na pedagogických fakultách v České republice úskalí vztahující se k našemu návrhu odhalila Cichá (2006 in Průcha, 2009, s. 859), která zjistila, že u řady studijních oborů není multikulturní výchova začleněna jako povinný předmět, takže se nestává součástí pedagogické způsobilosti všech budoucích učitelů. Tento stav může být do jisté míry považován za příčinu negativních postojů vyjadřovaných částí respondentů v prezentované empirické studii. Poněvadž jsou podle Clifta (1988) postoje k homosexualitě relativně trvalé a bývá obtížné je změnit, významným požadavkem je, že intervence v této oblasti musí mít longitudinální charakter.

Bylo prokázáno, že pro formování postojů vysokoškolských studentů je efektivní výuka s využitím audiovizuálních materiálů explicitně zobrazujícími lesbickou a gay tematiku, vč. dokumentů zachycujících předsudky majoritní společnosti k homosexuálům (srov. Cooley \& Burkholder, 2011). V českém jazyce je dostupná např. metodická př́ručka k filmům s lesbickou, gay, bisexuální a transgender tematikou Co vědět o sexuálních menšinách, jak o nich se žáky a žákyněmi mluvit a jak se na ně dívat (Sloboda, 2010). Využití audiovizuálních materiálů ve výuce může sloužit nejenom k osvojování vědomostí, ale především k vyvracení stereotypů a miskoncepcí o homosexualitě 
a poskytovat př́ležitost pro rozvoj pozitivního nahlížení na homosexuálně orientované jedince. Součástí výuky založené na práci s audiovizuálními materiály musí být kromě projekce filmů, dokumentů a spotů také analýza obsahu, zobecňování, pojmenovávání a reflektování viděné a prožívané skutečnosti. Tento způsob př́ípravy pokládá dostatečné základy, které mohou studenti uplatnit i při své budoucí pedagogické práci se žáky.

V souladu $\mathrm{s}$ transkulturním přístupem $\mathrm{k}$ výuce multikulturní výchovy lze do výuky zařadit prvky zážitkového učení. Jak podotýká Němec (2002), osobní prožitky a zkušenosti zůstávají uchovány v trvalé paměti studentů a jsou-li konceptualizovány, konfrontovány a diskutovány s jinými lidmi, mohou ovlivňovat postoje jedince a působit prostřednictvím transferu při řešení reálných problémů. Návrh didaktických možností za užití situačních a inscenačních metod podávají např. Smetáčková a Braun (2009) ve výukovém materiálu pro základní a střední školy Homofobie $v$ žákovských kolektivech. Navržené aktivity jsou vhodné rovněž pro vzdělávání studentů pedagogicky orientovaných studijních programů.

Z poznatků prezentovaných $\mathrm{v}$ předkládané studii je možné vyvodit závěr, že heterosexuálové, kteř́ znají někoho, kdo otevřeně přiznává svou homosexuální orientaci, všeobecně zastávají k homosexualitě pozitivnější postoje než ostatní. Uvedená skutečnost predikuje suportivní postoje k homosexuálům dokonce $\mathrm{u}$ jedinců $\mathrm{z}$ demografických skupin s hostilními normami (srov. Herek, 1991). Při zkoumání, zdali interakce mezi skupinami vede ke snižování předsudků vůči homosexualitě, Herek a Capitanio (1996) zjistili, že vztah mezi kontaktem a kladnými postoji heterosexuálů k homosexualitě je silnější, když respondenti uvádí větší počet kontaktů, jež mají důvěrný charakter a jsou udržovány s osobami, které svoji homosexuální orientaci veřejně přiznávají. Kontakt s osobami s homosexuální orientací je možné při přípravě studentů pedagogicky orientovaných studijních programů naplnit prostřednictvím besed či jiných forem výuky. Navíc, pokud budou homosexuální studenti vnímat akademické prostředí za bezpečné a podpůrné, povede to u nich pravděpodobně k většímu odhodlání k vnějšímu coming-outu (Arndt \& de Bruin, 2006). V tomto př́ipadě by mohli homosexuální studenti sami přispět k formování postojů heterosexuálních spolužáků. Obdobně mohou svým coming-outem ovlinit postoje studentů akademičtí pracovníci univerzit. Zde se potvrzuje, že postoje jednotlivců není možné změnit, aniž by došlo ke změně na institucionální úrovni. Školy (v našem případě univerzity připravující budoucí pedagogy) jako sociální organismus musí přijmout a dodržovat normy, které považují netolerantní a diskriminační chování vůči osobám s odlišnou sexuální orientací za neakceptovatelné. 


\section{Návrhy pro další výzkum}

Závěrem chceme naznačit další možnosti zkoumání. Poněvadž se mají pedagogové tendenci prezentovat jako profesní skupina bez předsudků (srov. Peréz-Testor et al., 2010), otázkou pro další výzkum je, do jaké míry postoje $\mathrm{k}$ homosexualitě měřené postojovými škálami vypovídají o jejich skutečných postojích, resp. do jaké míry korespondují s reálným chováním ve školním prostředí.

V didaktické rovině chybí dostatek empirických důkazů, zdali námi navržená opatření k formování postojů heterosexuálních studentů k homosexualitě vyvolávají žádoucí efekty a jaká je jejich trvalost.

Stěžejním tématem pro budoucí výzkum vidíme zmapování zkušeností homosexuálně orientovaných žáků základních a středních škol, které zažívají ve školním prostředí kvůli své odlišné sexuální orientaci. Poněvadž zahraniční studie využívají při zkoumání tohoto tématu převážně kvantitativní přístup (např. Kosciw et al., 2014, 2012), v českém prostředí by bylo vhodné realizovat šetření postavené na kvalitativním výzkumném designu, jenž umožňuje zachycení emic perspektivy (srov. Gall, Gall, \& Borg, 2006). V rámci navrhované studie by měl být komplexně zhodnocen fenomén diskriminace, s nímž se homosexuální žáci ve školním prostředí setkávají jak ze strany svých spolužáků, tak pedagogů, a jeho možné důsledky - v oblasti osobnostní a sociální.

Z uvedených návrhů pro další výzkum je patrné, že náměty studia tématu homosexuality v pedagogických vědách nejsou dosud zcela vyčerpány.

\section{Poděkování}

Autor děkuje redakci časopisu Pedagogická orientace a recenzentům za podnětné připomínky, které mu umožnily zkvalitnit text př́íspěvku a nahlížet na téma v širším kontextu.

\section{Literatura}

Adamczyk, A., \& Pitt, C. (2009). Shaping attitudes about homosexuality: The role of religion and cultural context. Social Science Research, 38(2), 338-351.

Allport, G. (1954). The nature of prejudice. New York: Addison Wesley.

Almeida, J., Johnson, R. M., Corliss, H. L., Molnar, B. E., \& Azrael, D. (2009). Emotional distress among LBGT youth: The influence of perceived discrimination based on sexual orientation. Journal of Youth and Adolescence, 38(7), 1001-1014. 
Anderssen, N. (2002). Does contact with lesbians and gays lead to friendlier attitudes? A two year longitudinal study. Journal of Community and Applied Social Psychology, 12(2), 124-136.

Arndt, M., \& de Bruin, G. (2006). Attitudes toward lesbians and gay men: Relations with gender, race and religion among university students. Psychology in Society, 33, 16-30.

Baker, J., \& Fishbein, H. (1998). The development of prejudice towards gays and lesbians by adolescents. Journal of Homosexuality, 36(1), 89-100.

Beere, C. A. (1990). Sex and gender issues: A handbook of tests and measures. Westport: Greenwood Press.

Besen, Y., \& Zicklin, G. (2007). Young men, religion and attitudes towards homosexuality. Journal of Men, Masculinities and Spirituality, 1(3), 250-266.

Bontempo, D. E., \& D'Augelli, A. R. (2002). Effects of at-school victimization and sexual orientation on lesbian, gay, or bisexual youths' health risk behavior. Journal of Adolescent Health, 30(5), 364-374.

Butler, K. (1995). Preservice teachers' knowledge and attitudes regarding gay men and lesbians: The impact of cognitive vs. affective educational interventions (Unpublished doctoral dissertation). Kent: Kent State University.

Calzo, J. P., \& Ward, L. M. (2009). Media exposure and viewers' attitudes toward homosexuality: Evidence for mainstreaming or resonance? Journal of Broadcasting and Electronic, 53(2), 280-299.

Clift, S. M. (1988). Lesbian and gay issues in education: A study of the attitudes of first-year students in a college of higher education. British Educational Research Journal, 14(1), 31-50.

Cochran, B. N., Stewart, A. J., Ginzler, J., \& Cauce, A. M. (2002). Challenges faced by homeless sexual minorities: Comparison of gay, lesbian, bisexual, and transgender homeless adolescents with their heterosexual counterparts. American Journal of Public Health, 92(5), 773-777.

Collier, K. L., Bos, H. M., \& Sandfort, T. G. (2012). Intergroup contact, attitudes toward homosexuality, and the role of acceptance of gender non-conformity in young adolescents. Journal of Adolescence, 35(4), 899-907.

Cooley, J. J., \& Burkholder, G. J. (2011). Using video and contact to change attitudes toward gay men and lesbians. Journal of Social, Behavioral, and Health Sciences, 5(1), 83-90.

Čadová, N. (2014). Postoje veřejnosti k právům homosexuálů - červen 2014. Praha: Sociologický ústav Akademie věd České republiky.

Ďurd'ovič, M. (2013). Postoje veřejnosti k právům homosexuálů - květen 2013. Praha: Sociologický ústav Akademie věd České republiky.

Eisenberg, M. E., \& Resnick, M. D. (2006). Suicidality among gay, lesbian and bisexual youth: The role of protective factors. Journal of Adolescent Health, 39(5), 662-668.

Emmerová, L., Koštálová, V., Pícha, T., Sedláčková, M., \& Winzbergerová, A. (2010). Názory na odlišnou sexuální orientaci. Dostupné z http://www.socioweb.cz/index. php?disp=temata\&shw=350\&lst $=108$

Farr, M. T. (2000). "Everything I didn't want to know I learned in lit class": Sex, sexual orientation, and student identity. International Journal of Sexuality and Gender Studies, 5(2), 205-213.

Fazio, R. H. (1990). Multiple processes by which attitudes guide behavior: The MODE model as an integrative framework. Advances in Experimental Social Psychology, 23, 75-109.

Fontaine, J. H. (1998). The sound of silence: Public school response to the needs of gay and lesbian youth. Journal of Gay and Lesbian Social Services, 7(4), 101-109.

Gall, M. D., Gall., J. P., \& Borg, W. R. (2006). Educational research: An introduction. Boston: Allyn \& Bacon. 
Gato, J., Fontaine, A. M., \& Carneiro, N. S. (2012). Multidimensional scale of attitudes toward lesbians and gay men: Construction and preliminary validation. Paidéia, 22(51), 11-20.

Graham, C. C. (2012). Teacher' explicit and implicit attitudes toward homosexuality: The role of internal and external motivation to respond without prejudice (Unpublished doctoral dissertation). Philadephia: University of Pennsylvania.

Haas, A. P., Eliason, M., Mays, V. M., Mathy, R. M., Cochran, S. D. D’Augelli, A. R. ... Clayton, P. J. (2011). Suicide and suicide risk in lesbian, gay, bisexual and transgender populations: Review and recommendations. Journal of Homosexuality, 58(1), 10-51.

Hansen, G. L. (1982). Measuring prejudice against homosexuality (homosexism) among college students: A new scale. Journal of Social Psychology, 117(2), 233-236.

Heinze, J. E., \& Horn, S. S. (2009). Intergroup contact and beliefs about homosexuality. Journal of Youth and Adolescence, 38(7), 937-951.

Herek, G. M. (1988). Heterosexuals' attitudes toward lesbians and gay men: Correlates and gender differences. Journal of Sex Research, 25(4), 451-477.

Herek, G. M. (1991). Stigma, prejudice, and violence against lesbians and gay men. In J. C. Gonsiorek \& J. D. Weinrich (Eds.), Homosexuality: Research implications for public policy (s. 60-80). Newbury Park: Sage.

Herek, G. M. (1994). Assessing heterosexuals' attitudes toward lesbians and gay men: A review of empirical research with the ATLG scale. In B. Greene \& G. M. Herek (Eds.), Lesbian and gay psychology: Theory, research, and clinical application (s. 206-228). Thousand Oaks: Sage.

Herek, G. M. (1999). Sex differences in how heterosexuals think about lesbians and gay men: Evidence from survey context effects. The Journal of Sex Research, 36(4), 348-360.

Herek, G. M. (2000a). Sexual prejudice and gender: Do heterosexuals' attitudes toward lesbians and gay men differ? Journal of Social Issues, 56(2), 251-266.

Herek, G. M. (2000b). The psychology of sexual prejudice. Current Directions in Psychological Science, 9(1), 19-22.

Herek, G. M., \& Capitanio, J. P. (2000). "Some of my best friends“: Intergroup contact, concealable stigma, and heterosexuals' attitudes toward gay men and lesbians. Personality and Social Psychology Bulletin, 22(4), 412-424.

Hewitt, E. C., \& Moore, L. D. (2002). The role of lay theories about the etiologies of homosexuality in attitudes toward lesbian and gay men. Journal of Lesbian Studies, 6(3-4), 59-72.

Hudson, W. W., \& Ricketts, W. A. (1980). A strategy for the measurement of homophobia. Journal of Homosexuality, 5(4), 357-372.

Janík, T., Spilková, V., \& Píšová, M. (2014). Standard a kariérní systém učitele: problémy předložené koncepce v širších souvislostech. Pedagogická orientace, 24(2), 259-274.

Janošová, P. (2000). Homosexualita v názorech současné společnosti. Praha: Karolinum.

Jellison, W. A., McConnell, A. R., \& Gabriel, S. (2004). Implicit and explicit measures of sexual orientation attitudes: Ingroup preferences and related behaviors and beliefs among gay and straight men. Personality and Social Psychology Bulletin, 30(5), 629-642.

Johnson, B., \& Christensen, L. (2012). Educational research: quantitative, qualitative, and mixed approaches. Thousand Oaks: Sage.

Kamanová, L. (2014). Sexuální výchova v rodině: co víme z výzkumných studií. Studia paedagogica, 19(3), 29-46.

Karmelitánské nakladatelství. (2002). Katechismus katolické církve. Kostelní Vydří: Karmelitánské nakladatelství. 
Kelly, J. (2001). Attitudes towards homosexuality in 29 nations. Australian Social Monitor, 4(1), $15-22$.

Kerns, J. G., \& Fine, M. A. (1994). The relation between gender and negative attitutes toward gay men and lesbians: Do gender role attitudes mediate this relation? Sex Roles, 31(5-6), 297-307.

Kite, M. E., \& Deaux, K. (1986). Attitudes toward homosexuality: Assessment and behavioral consequences. Basic and Applied Social Psychology, 7(2), 137-162.

Kosciw, J. G., Greytak, E. A., Bertkiewicz, M. J., Boesen, M. J., \& Palmer, N. A. (2012). The 2011 national school climate survey. New Work: Gay, Lesbian and Straight Education Network.

Kosciw, J. G., Greytak, E. A., Palmer, N. A., \& Boesen, M. J. (2014). The 2013 national school climate survey. New Work: Gay, Lesbian and Straight Education Network.

Lambert, E. G., Ventura, L. A., Hall, D. E., \& Cluse-Tolar, T. (2006). College students's views of gay and lesbian issues: Does education make a difference? Journal of Homosexuality, 50(4), $1-30$.

Larsen, R. S., Reed, M., \& Hoffman, S. (1980). Attitudes of heterosexuals toward homosexuality: A Likert-type scale and construct validity. Journal of Sex Research, 16(3), 245-257.

Mishna, F., Newman, P. A., Daley, A., \& Solomon, S. (2009). Bullying of lesbian and gay youth: A qualitative investigation. The British Journal of Social Work, 39(8), 1598-1614.

Morrison, T. G., Kenny, P., \& Harrington, A. (2005). Modern prejudice toward gay men and lesbian women: Assessing the viability of a measure of modern homonegative attitudes within an Irish context. Genetic, Social, and General Psychology Monographs, 131(3), 219-250.

Morrison, T. G., Parriag, A. V., \& Morrison, M. A. (1999). The psychometric properties of the Homonegativity Scale. Journal of Homosexuality, 37(4), 111-126.

MŠMT. (2015). Výkonové ukazatele. Dostupné z http://dsia.uiv.cz/vystupy/vu_vs_f2.html

Murdock, T. B., \& Bolch, M. B. (2005). Risk and protective factors for poor school adjustment in lesbian, gay, and bisexual (LGB) high school youth: Variable and person-centered analysis. Psychology in the School, 42(2), 159-172.

Němec, J. (2002). Edukativní význam hry a zážitku v postmoderní společnosti. In S. Střelec (Ed.), Studie z teorie a metodiky výchovy (s. 92-101). Brno: MSD.

Network Media Service. (2007). Rovnost je COOL! Závěrečná zpráva z kvantitativního výzkumu. Praha: Network Media Service.

Pechová, 0. (2009). Diskriminace na základě sexuální orientace. E-psychologie, 3(3), 1-16.

Pérez-Testor, C., Behar, J., Davins, M., Conde Sala, J. L., Castillo, J. A., Salamero, M., ... Segarra, S. (2010). Teachers' attitudes and beliefs about homosexuality. The Spanish Journal of Psychology, 13(1), 138-155.

Průcha,J.(2009). Multikulturní výchova. In J.Průcha (Ed.), Pedagogická encyklopedie(s. 857-861). Praha: Portál.

Raja, S., \& Stokes, J. P. (1998). Assessing attitudes toward lesbians and gay men: The modern homophobia scale. Journal of Gay, Lesbian, and Bisexual Identity, 3(2), 113-134.

Rasch, D., Teuscher, F., \& Volker, G. (2007). How robust are tests for two independent samples? Journal of Statistical Planning and Inference, 137(8), 2706-2702.

Rezková, M. (2003). Jakjsme tolerantní. Praha: Sociologický ústav Akademie věd České republiky.

Riggs, A., Rosenthal, A. R., \& Smith-Bonahue, T. (2011). The impact of a combined cognitiveaffective intervention on pre-service teachers' attitudes, knowledge, and anticipated professional behaviors regarding homosexuality and gay and lesbian issues. Teaching and Teacher Education, 27(1), 201-209. 
Rivers, I., \& D'Augelli, A. R. (2001). The victimization of lesbian, gay, and bisexual youths. In A. R. D'Augelli \& C. J. Patterson (Eds.), Lesbian, gay and bisexual identities and youth: Psychological perspectives (s. 199-223). New York: Oxford University Press.

Røthing, Å, \& Svendsen, S. H. B. (2010). Homotolerance and heterosexuality as Norwegian values. Journal of LGBT Youth, 7(2), 147-166.

Savin-Williams, R. C. (1994). Verbal and physical abuse as stressors in the lives of lesbian, gay male, and bisexual youths: Associations with school problems, running away, substance abuse, prostitution, and suicide. Journal of Consulting and Clinical Psychology, 62(2), 261-269.

Serdahely, W. J., \& Ziemba, G. J. (1984). Changing homophobic attitudes through college sexuality education. Journal of Homosexuality, 10(1-2), 109-116.

Schellenberg, E. G., Hirt, J., \& Sears, A. (1999). Attitudes toward homosexuals among sudents at a Canadian University. Sex Roles, 40(1-2), 139-152.

Sloboda,Z. (2010). Cověděto sexuálních menšinách,jakonich sežákya žákyněmi mluvitajakse na ně dívat. Dostupné z http://lgbt.poradna-prava.cz/folder02/metodika_zlom_cista_final.pdf

Smetáčková, I. (2010). Běžný den v životě žen a mužů - představy dívek a chlapců o vlastní budoucnosti. Studia paedagogica, 15(1), 107-124.

Smetáčková, I., \& Braun, R. (2009). Homofobie v žákovských kolektivech. Praha: Úřad vlády České republiky.

Stehlíková, D., Procházka, I., \& Hromada, J. (1995). Homosexualita, společnost a AIDS v ČR. Praha: Sdružení organizací homosexuálních občanů (SOHO) v České republice.

Thatcher, W. G., \& Chandler, S. (2013). Heterosexual attitudes towards homosexuality: An exploratory study of college student perceptions. College Student Affairs Journal, 31(1), 27-39.

Tsang, E. (1994). Investigating the effect of race and apparent lesbianism upon helping behaviour. Feminism and Psychology, 4(3), 469-471.

Tuček, M. (2014). Tolerance k vybraným skupinám obyvatel - březen 2014. Praha: Sociologický ústav Akademie věd České republiky.

Tuček, P., \& Holub, J. (1994). Epidemiologicko-sociologické šetření názorů občanů České republiky na onemocnění AIDS. Praha: Nadace Společně proti AIDS.

Vaculík, M., \& Červenková, P. (2007). Formování postoje k homosexualitě. Československá psychologie, 51(1), 58-71.

Vincent, W., Parrott, D. J., \& Peterson, J. L. (2011). Effects of traditional gender role norms and religious fundamentalism on self-identified heterosexual men's attitudes, anger, and aggression toward gay men and lesbians. Psychology of Men and Masculinity, 12(4), 383-400.

Wall, V. (1995). Beyond tolerance: Gays, lesbians and bisexuals on campus: A handbook of structured experiences and exercises for training and development. Washington: American College Personnel Association.

Weiss, P., \& Zvěřina, J. (1997). Sexuální postoje obyvatel České republiky: Výsledky národního výzkumu. Československá psychologie, 41(3), 208-215.

Weiss, P., Procházka, I., \& Zvěřina, J. (1998). Postoje české populace k homosexualitě. Československá psychiatrie, 94(8), 475-479.

Woodford, M. R., Silverschanz, P., Swank, E., Scherrer, K. S., \& Raiz, L. (2012). Predictors of heterosexual college students' attitudes toward LGBT people. Journal of LGBT Youth, 9(4), 297-320.

Wright, L. W., Adams, H. E., \& Bernat, J. (1999). Development and validation of the homophobia scale. Journal of Psychopathology and Behavioral Assessment, 21(4), 337-347. 
Wyatt, T., Oswalt, S. B., White, Ch., \& Peterson, F. L. (2008). Are tomorrow's teachers ready to deal with diverse students? Teacher candidates' attitudes toward gay men and lesbians. Teacher Education Quarterly, 35(2), 171-185.

Yip, A. (2005). Queering religious texts: An exploration of british non-heterosexual christians' and muslims' strategy of constructing sexuality affirming hermeneutics. Sociology, 39(1), 47-65.

Zelová, A. (2008). Makrosociální jevy a procesy. In J. Výrost \& I. Slaměník (Eds.), Sociální psychologie (s. 33-45). Praha: Grada Publishing.

\title{
Autor
}

doc. PhDr. Petr Hlad'o, Ph.D., Mendelova univerzita v Brně, Institut celoživotního vzdělávání, Zemědělská 5, 61300 Brno, e-mail: petr.hlado@mendelu.cz

\section{Attitudes of university students of educationally-oriented study programs towards homosexuality measured on the Homosexuality Attitude Scale}

\begin{abstract}
The aim of the study is to assess the attitudes of students of educationallyoriented study programs towards homosexuality and determine what they are influenced by. The paper argues the importance of the topic in education, and gives an overview of conclusions of selected Czech and foreign research studies dealing with the issue of heterosexuals' attitudes towards homosexuality. Furthermore, the aims, methodology and findings from the actual research survey are presented. Finally, recommendations for pre-graduate education of future teachers are presented and suggestions for further research are given. The aim of the research was to determine the attitudes of students of educationally-oriented study programs towards homosexuality. The research instrument was the Homosexuality Attitude Scale developed by Kite and Deaux (Cronbach's alpha $=0.91$ ). Data collection took place in October and November 2014. The sample consists of 1,140 respondents. On average, the attitudes of students of pedagogical study programmes towards homosexuality are relatively positive (average HAS score $=88.77$ from a theoretical range of $12-105$; lower values indicate a more negative attitude towards homosexuality). Significantly more negative attitudes towards homosexuality were found in men, students of initial years of study, and members of the Roman Catholic or other church or religious society. The findings imply a need to form attitudes of future teachers towards homosexuality by means of cognitive-affective interventions in formal education.
\end{abstract}

Keywords: attitudes towards homosexuality, attitudes of educators, Homosexuality Attitude Scale, homosexuality, sexual prejudice, sexual discrimination 